\title{
A Brief Review of Genetic Approaches to the Study of Food Preferences: Current Knowledge and Future Directions
}

\author{
Antonietta Robino ${ }^{1, *(1)}$, Maria Pina Concas ${ }^{1}$, Eulalia Catamo ${ }^{1}$ and Paolo Gasparini ${ }^{1,2}$ \\ 1 Institute for Maternal and Child Health, IRCCS “Burlo Garofolo”, Via dell'Istria 65/1, 34137 Trieste, Italy \\ 2 Department of Medical Sciences, University of Trieste, Strada di Fiume, 447, 34149 Trieste, Italy \\ * Correspondence: antonietta.robino@burlo.trieste.it
}

Received: 24 January 2019; Accepted: 25 July 2019; Published: 26 July 2019

\begin{abstract}
Genetic variation plays a crucial role in individual differences in food preferences which ultimately influence food selection and health. Our current understanding of this pathway has been informed through twin studies (to assess the heritability of food preferences), candidate gene studies, and genome-wide association studies (GWAS). However, most of this literature is mainly focused on genes previously identified as having taste or smell functions. New data suggests that genes not associated with taste or smell perception may be involved in food preferences and contribute to health outcomes. This review highlights these emerging findings and suggests a polygenic risk assessment approach to explore new relationships between food preferences and health risks.
\end{abstract}

Keywords: genetics; food preferences; heritability; candidate gene; GWAS; adiposity; polygenic risk score

\section{Introduction}

Food preferences are shaped by a high number of environmental, cultural, and nutritional factors, including genetic ones. The first evidence for genetic influences on food preferences came from family and twin studies [1-12]. However, over the last few decades, rapid advances in molecular genetics have revolutionized the understanding of individual differences in many aspects of human behavior. These advances give researchers the tools to conduct genetic association studies on a large scale to better understand the role of specific gene loci in sensory perceptions, food liking/disliking, preference, and intake, as well as on food-related habits [13-18].

To date, the vast majority of studies on food liking and preference have focused on identifying specific genes and traits associated with sensory perceptions (mainly taste and smell perception). The effects of taste and smell genes on food habits [19-36] and health status [30,31,37-48] have also been extensively investigated. However, gaps in understanding still exist, and emerging evidence suggests that novel genes (not necessarily related to taste or smell perception) may play a critical role in these relationships [13-16].

Thus, a potential new area in nutrition research is the investigation of the genetic bases of food preferences, broadly defined to include both taste/smell-related and non-related genes.

Obtaining a comprehensive picture of genetic effects on food preferences and habits and their consequences for food-related diseases, such as being overweight or obesity, is of considerable public health importance and interest to the food industry.

This review focused on current knowledge, linking genetic variability to food preferences. Specifically, we reviewed studies on food preferences (defined as the selection of one food rather than another) and food liking (meaning the degree of liking or disliking towards a food). 


\section{Genetic Dissection of Food Preferences}

The genetic background of a trait can be investigated through several methods. Firstly, heritability analysis allows one to estimate the proportion of variation of a phenotype, which is due to genetic differences between individuals. However, heritability studies do not provide any information on specific genes and polymorphisms related to a given trait. Specific information can be identified through genetic association analysis such as candidate gene and genome-wide approaches. A candidate gene study investigates variations within specific genes of interest selected on the basis of existing knowledge or hypotheses. In contrast, a Genome-Wide Association Study (GWAS) is conducted without suppositions or previous knowledge and the whole genome is scanned so that new genetic variants may be discovered [49-51].

Here, we report different approaches through which the genetics of food preferences can be dissected. Firstly, we review studies that provide evidence for a genetic basis of food preferences (heritability studies) and then studies that identified underlying genes (candidate genes and genome-wide association). Finally, we describe the possible relationships between genes linked to food preferences and health status, and we present an example of the predictive power of polymorphisms associated with vegetable liking on adiposity measures.

\subsection{Heritability Studies}

Heritability is the proportion of the phenotypic variation in a population explained by genetic effects; it is a measure of the inheritance of a trait. Usually, heritability estimation requires data where familial relationships are known (twins or family studies) and does not provide information about which genes are responsible for the trait. Heritability has been widely estimated in twin studies, where monozygotic twins (identical twins with almost no differences in their DNA) are compared to dizygotic twins (fraternal twins who share, on average, half of their DNA). This comparison allows one to evaluate the proportion of variation of a trait ascribable to genetic factors, while the remaining variance is assumed to derive from environmental factors. Heritability estimation ranges from 0 to 1: a high value indicates that genetics plays a major role, while low values indicate that most of the variation is due to environmental factors. High heritability does not necessarily imply that a single gene is the cause of trait variation. It is possible that multiple genes, each of them having a small effect, contribute to this variation [52].

Evidence on the heritability of food preferences has been reported in both adult and children twin studies. For example, studies of 3-5 year-old children provide evidence for high or moderate heritability for liking of vegetables (from 0.37 and 0.54 ), fruits (from 0.51 to 0.53 ), and proteins (from 0.48 to 0.78$)[4,5]$. Moderate heritability for specific food preferences such as vegetables (0.54), fruits (0.49), meat or fish (0.49), and dairy (0.44) has also been observed in adolescents (18-19 years of age) [6]. Similar findings have been reported in adults. In a cohort of $\sim 600$ adult female twins in the UK, Keskitalo and colleagues reported that $0.49,0.54$, and 0.53 of the variation in liking for a sweet solution, liking and use-frequency of different sweet foods (sweet desserts, sweets, sweet pastry, ice cream, hard candy, and chocolate), respectively, was explained by genetic factors [8,9]. Similarly, a study in young adult Finnish twins showed that genetic effects account for $0.18-0.58$ of the variation in the pleasantness of oral pungency, spicy foods, and pungent sensations [10]. In the same cohort, genetic influences on sour foods were studied, and 0.14 and 0.31 of the variation in pleasantness and intensity of orange juice spiked with citric acid was reported [11]. Moreover, these same authors also found that genetic effects accounted for $0.34-0.50$ of the variation in pleasantness and use-frequency of sour foods categorized into three groups as follows: sour fruits and berries (red currant, red currant juice, cranberry, lingonberry, lemon, and rhubarb), sour dairy products (natural cultured milk, natural yogurt, and sour milk), and less-sour berries and fruits (strawberry, orange, blueberry, peach, and banana) [11].

Differences in heritability results across studies can be explained by the small sample size of most studies and by the minimal number of foods analyzed (i.e., different from study to study and mainly focused on the taste perception of foods). Moreover, differences in the data collection and analysis (i.e., 
age differences of participants, use of different questionnaires and measurements, analysis of single foods or a set of clustered foods) could also be responsible for this variability.

More recently, a large study of more than 2000 UK twins analyzed the heritability of different liking patterns using data from an online food liking-disliking questionnaire including 87 different foods and beverages. This study revealed four food-liking patterns by principal component analysis (PCA): fruit and vegetables; sweet and high carbohydrates; meat; distinctive tastes (including chili pepper, garlic, or other foods with strong taste). Moderate heritabilities were obtained for all of them (fruit and vegetables: 0.36 ; sweet and high carbohydrates: 0.52 ; meat: 0.44 ; distinctive tastes: 0.58 ), corroborating past works on genetic influences of food liking-disliking [12]. However, similar heritability estimates reached by studies with both large and small sample size suggest that environmental factors also play a crucial role.

Overall, these studies are useful in providing a quantitative estimate of the heritability of food preferences and in supporting the idea that genetic determinants play a role. However, as already mentioned, they do not give information concerning specific genes accounting for food preferences.

\subsection{Candidate Gene Studies}

A candidate gene study requires an "a priori" hypothesis based on a potential role of a given gene on a given trait of interest [53]. Regarding food preferences, this approach has been used to examine the possible role of polymorphisms in genes already known to be involved in taste or smell perceptions. These two senses allow us to recognize and to discriminate foods and are among the most important determinants of food liking/disliking [54-56]. For these reasons, DNA polymorphisms in taste and smell genes have played an important role in individual variability on food choices.

\subsubsection{Taste Receptor Genes}

It is well known that genetic factors influence taste perception. Genes encoding taste receptors have been identified and genetic variability of sweet, umami, and bitter perceptions have been intensely investigated, although knowledge gaps exist for sour and salty perception [19-37]. As stated above, comprehensive reviews have already been published on the relationship between variations in taste receptors and food preferences [38-44], thus in the present review, we only present a few examples.

A very well-known example is that of the TAS2R38 bitter receptor, a major contributor to individual differences in bitter taste perception of PROP (6-n-propylthiouracil) or PTC (phenylthiocarbamide). About $30 \%-40 \%$ of the European population is taste-blind to these compounds or perceive them as weakly bitter (so-called non tasters), while the remaining $70 \%-60 \%$ can perceive them as moderately or intensely bitter (so-called tasters). Three SNPs (Single Nucleotide Polymorphisms) in the TAS2R38 gene (rs1726866, rs10246939, rs713598) result in three amino acid substitutions defining two main haplotypes, namely AVI and PAV, that confer differences in the ability to taste PTC/PROP. Indeed, individuals homozygous for the AVI haplotype are mainly non tasters, while homozygous for the PAV haplotype and heterozygous individuals are likely to be tasters $[19,20,57,58]$.

Although controversial results have emerged in the literature, the variation in the ability to perceive PROP has been widely related to preferences for different foods such as brassica vegetables, other bitter foods, sweets, added fat, spicy foods, and alcoholic beverages [37,38,59-62]. For example, Mennella and collaborators showed that in children, but not in adults, TAS2R38 variations partially explained individual preferences for sucrose or beverages and cereals with a high sugar content [63]. A study in Malaysian adults showed mixed results. Specifically, they reported that aversions to individual foods such as green tea, mayonnaise, and whipped cream were associated with TAS2R38 genotypes, while no associations were observed for vegetables and sweet/fatty foods [64]. More recently, a study by Shen et al. showed that AVI/AVI subjects liked brassica vegetables more than PAV/AVI and PAV/PAV individuals [65]. In another recent work, Perna and collaborators reported that one specific polymorphism in the TAS2R38 gene was associated with preferences for beer, butter, and cured meat [66]. However, a link between TAS2R38 genetic variants and food liking has not been 
observed in other studies and several reasons could be responsible for the inconsistent findings such as food assessment methods, sample size, cultural habits, or other environmental factors that may influence the association.

Evidence for a relationship between other bitter taste receptor genes and liking of common foods and beverages have also been reported. For example, variation in the TAS2R19 bitter-taste gene showed associations with grapefruit juice bitterness and liking [37], while another bitter-taste gene, TAS2R43, has been related to coffee liking [67]. Data also suggested a possible influence of genetic variation in the TAS1R3 sweet receptor gene on sweet preferences in children [68], as well as a link between variations in the CD36 gene (responsible for fat taste perception) and fat preferences [31].

The studies reviewed above have limited implications for general food preferences because they only analyze one or few genes (or SNPs) and they examine liking for just one or few foods. To address this shortcoming, our group examined the relationship between a broad spectrum of food preferences and DNA variants in several taste and olfaction genes in a large cohort of $>400$ individuals. Statistically significant associations were identified for genes involved in chemosensory functions (i.e., TRPV1 and TAS1R2) or in signal transduction (i.e., PLC 32 and ITPR3). One of the most interesting associations was found between the TAS1R2 gene (coding for a sweet taste receptor) and liking of alcoholic beverages, according to data reporting a link between ethanol preference and liking for sweet taste. Specifically, the lower frequent allele for two different SNPs (rs3935570 and rs4920566) in the TAS1R2 gene were positively associated with the liking of vodka and white wine. Another noteworthy association was detected for tea and the PLC $\beta 2$ gene, a marker for type II taste bud cells, which is involved in the caffeine response and is also expressed in the sensory cells of the olfactory epithelium. In this case, the rarest allele of rs2290550 SNP was negatively correlated with tea liking [15].

\subsubsection{Olfactory Receptor Genes}

Humans vary in their capacity to perceive several odors, and their variation in olfactory receptor (OR) genes may be responsible for these differences [69,70]. Despite more than 400 genes/receptors being involved in smell perception, little is known about the link between these genes and specific odorants as well as their possible influence on food preferences. One of the most recognized examples is the role of the olfactory receptor gene $O R 7 D 4$, which is partially responsible for individual differences in the ability to smell androsterone [69]. Androsterone is undetectable for some people, others define it as foul smelling or urine and sweat smelling, while others describe it as sweet or floral smelling. Two SNPs in the OR7D4 gene are responsible for two amino acid substitutions that impair the ability to perceive androstenone [70]. Androstenone is present in the meat of male pigs. A recent study confirmed that OR7D4 variants were associated with the sensory perception of pork meat containing androstenone as well as lower liking for the flavor and odor of pork meat by androstenone-sensitive individuals [71].

Another example is the OR2J3 gene, which is associated with individual differences in detecting Cis-3-hexen-1-ol (C3HEX), an odorant with a green/grassy smell and is present in several fruits and vegetables. Polymorphisms in this gene are responsible for amino acid substitutions impairing the ability to smell C3HEX. Subjects can be classified as C3HEX-sensitive or C3HEX-insensitive [72,73]. Moreover, foods spiked with C3HEX were less acceptable than the unspiked foods; however, the reductions in acceptability were more marked in C3HEX-sensitive individuals if compared to C3HEX-insensitive individuals [74].

Finally, studies examined variation in the OR5A1 gene, related to $\beta$-ionone odor sensitivity. $\beta$-ionone aroma is a fruity/floral aroma that is present in several foods and beverages [75-78]. A series of studies by Jaeger and co-workers showed that a DNA variation (rs6591536 SNP) in the OR5A1 gene is the causal variant for $\beta$-ionone odor sensitivity, explaining $96.3 \%$ of the phenotypic variation. They also reported that $\beta$-ionone sensitive individuals can easily differentiate between foods (such as milk chocolate or apple juice) with and without added $\beta$-ionone, and they can also recognize $\beta$-ionone 
in foods when compared to less-sensitive individuals. Moreover, sensitive individuals prefer foods without $\beta$-ionone rather than with $\beta$-ionone [79].

\subsection{GWA Studies}

Over the past decade, the GWAS approach has become one of the most common tools for the identification of genes associated with complex traits and diseases. In these studies, a large number of participants are genotyped for a large number of genetic markers (usually SNPs) covering the whole genome and their relationships with the trait of interest are examined, allowing for the identification of novel gene variants and genomic loci [80].

To date, very few GWAS have been conducted on food preferences, which are summarized in Table 1. Although a genome-wide scan typically analyzes thousands or even millions of SNPs, Table 1 reports only GWAS significant SNPs with $p$-value $<5 \times 10^{-8}$. This $p$-value is equivalent to the Bonferroni-corrected threshold $(\alpha=0.05)$ for 1 million independent variants (approximately the number of independent SNPs analyzed in a GWAS).

The first GWAS was carried out on cilantro (or coriander) liking in a large cohort of unrelated European subjects belonging to the 23andMe cohort [81], who responded to an online questionnaire asking whether they taste cilantro as soapy and whether they like it. An association among the rs72921001 SNP, soapy taste, and disliking of cilantro was found. This SNP falls within a cluster of eight olfactory receptor genes on chromosome 11. Among them, the authors suggested that a good candidate for cilantro preferences could be the OR6A2 gene coding for a receptor that can be activated by several aldehydes responsible for the characteristic odor of cilantro [18].

More recently, we conducted the first GWAS on red and white wine preference assessed by survey-reported food liking in 3885 adults coming from different geographic areas (Italy, the Netherlands, and Central Asia). In this work, we detected a significant association between white wine liking and rs9276975 SNP in the HLA-DOA gene, encoding for a non-canonical MHC (major histocompatibility complex) II molecule. Although the mechanism of how MHC could be linked to wine preferences is unknown, the possible involvement of the olfactory system was hypothesized [16]. Moreover, another GWAS on the liking of 20 different foods was carried out on a large cohort of 4611 individuals, which identified 15 novel significant variants associated with 12 different foods. Some of these variants are located within genes that might represent good candidates for food choices. Interestingly, none of them belong to taste or olfactory receptor gene families, but are likely to be involved in reward response to food (i.e., BPNT1, IRX4, CNTN5, and CSMD1 genes). For example, an association was detected between the liking of bacon and rs140738262 SNP in the CNTN5 gene. This polymorphism also showed marginal association with the liking of other fatty foods such as lamb, pork chops, and goat cheese. This gene is expressed in the brain and has previously been associated with anorexia nervosa, suggesting a possible link with preferences for palatable food and the responsivity of the brain reward system to these foods. For vegetables, an association between chicory liking and rs138369603 SNP in the CSMD1 gene has emerged. We hypothesized a possible role of this gene in the regulation of the food reward response since its variants were linked to differential activation of the cuneus, an area possibly involved in central reward processing [17].

Overall, these results represent a step in understanding the biological bases of food liking and suggest that the GWAS approach may be useful in identifying novel candidate genes for food preferences. Nowadays, thanks to the reduction of SNP genotyping costs as well as to the existence of large population biobanks, GWA studies could contribute to identifying many more loci, which will enhance insight into the genetic architecture of food preferences. Thus, further studies should be conducted to confirm previous findings, to extend the range of examined foods, and to also analyze other food groups. 
Table 1. GWA studies of food liking.

\begin{tabular}{|c|c|c|c|c|c|c|}
\hline Reference & Subjects $(n)$ & Population & Food Liking Assessment & Associated Trait & SNP & Locus \\
\hline Eriksson et al., 2012 [18] & 26,455 & Unrelated (European) & $\begin{array}{l}\text { Responses to an online survey asking } \\
\text { the following questions: } \\
\text { - Does fresh cilantro taste like soap to } \\
\text { you?" (Yes/No/I'm not sure) } \\
\text { - Do you like the taste of fresh (not dried) } \\
\text { cilantro?" (Yes/No/I'm not sure) }\end{array}$ & Cilantro & rs72921001 & OR6A2 \\
\hline Pirastu et al., 2015 [16] & 3885 & $\begin{array}{l}\text { Isolated population (European } \\
\text { and Central Asia) }\end{array}$ & $\begin{array}{l}\text { Survey-reported food liking } \\
\text { (5-point scale or 9-point scale) }\end{array}$ & White wine & rs9276975 & $H L A-D O A$ \\
\hline Pirastu et al., 2016 [17] & 4611 & $\begin{array}{l}\text { Isolated population (European } \\
\text { and Central Asia) }\end{array}$ & $\begin{array}{l}\text { Survey-reported food liking } \\
\text { (5-point scale or 9-point scale) } \\
\text { (5-point scale or 9-point scale) }\end{array}$ & $\begin{array}{c}\text { Artichokes } \\
\text { Artichokes } \\
\text { Artichokes } \\
\text { Broccoli } \\
\text { Broccoli } \\
\text { Broccoli } \\
\text { Bacon } \\
\text { Oil or Butter on Bread } \\
\text { Blue Cheese } \\
\text { Ice Cream } \\
\text { Liver } \\
\text { Coffee }\end{array}$ & $\begin{array}{c}\text { rs28849980 } \\
\text { rs28849980 } \\
\text { rs8034691 } \\
\text { rs2530184 } \\
\text { rs9832668 } \\
\text { rs138369603 } \\
\text { rs140738262 } \\
\text { rs6661761 } \\
\text { rs12994253 } \\
\text { rs2035613 } \\
\text { rs34088951 } \\
\text { rs145671205 }\end{array}$ & $\begin{array}{c}\text { CCRN4L } \\
\text { ADAMTS19-CHSY3 } \\
\text { LOC100128714 } \\
\text { NA } \\
\text { RYBP } \\
\text { CSMD1 } \\
\text { CNTN5 } \\
\text { BPNT1 } \\
\text { KCMF1-TCF7L1 } \\
\text { IRX4 } \\
\text { RNU6-66 } \\
\text { FIBIN }\end{array}$ \\
\hline
\end{tabular}

Associated trait refers to the associated food liking; SNP column shows the name polymorphism; Locus column refers to the gene closest to the most significant SNP; GWA refers to Genome-Wide Association. 


\section{From genetic Variations in Food Preference Genes to Health}

There is a well-developed body of research examining the relationships between taste receptor genes and their downstream effects on food preferences and intake, which may in turn affect nutritional and health status [31,43-48]. These studies are reviewed elsewhere [82], however a few salient examples are discussed here. For instance, SNPs in the TAS1R2 and TAS1R3 genes, which codify for sweet taste receptors and are related to a higher preference and intake of sweet foods, have also been associated with increased dental caries $[46,83,84]$. Another example is the relationship between variations in the TAS2R38 bitter taste gene and eating behavior as well as anthropometric and adiposity measures. Increased disinhibition has been described in women carrying the PROP-insensitive allele for the rs1726866 SNP [85]; while another finding reported higher BMI and waist circumference among PROP non-taster women with low dietary restraint [86]. In another study, differences in body fat percentage were associated with the three TAS2R38 genetic variants, while no significant relationships with BMI and eating behavior were found [87]. Other studies did not support a relationship between TAS2R38 variants and adiposity measures $[64,86-88]$. These inconsistent results could be ascribed to the presence of several confounding factors (i.e., sex, age, ethnicity, etc.) that may modulate the relationship among taste receptors and health status parameters.

Differences in bitter taste perception have also been associated with bitter taste receptor mRNA levels in taste cells $[89,90]$, suggesting that gene expression is another factor to consider when the relationship with health measures is studied. Moreover, recent findings showed that the gene expression profile of fungiform taste papillae differs between lean and obese subjects [91]. Together, these findings highlight the need to conduct future studies to clarify their association.

Recent evidence also raises the possibility that taste and smell receptors residing in different bodily tissues may have multiple functions in health and disease. For example, taste receptors are also expressed in extra-oral tissues, such as the gastrointestinal tract, where they seem to be involved in digestive functions or homeostasis and energy metabolism [92-103].

It is also well known that the sense of smell is impaired in neurodegenerative diseases $[104,105]$ and associations between olfactory genes (expressed in olfactory and non-olfactory tissues) and diet-related diseases such as obesity have also been demonstrated [104,106,107]. Notably, the OR7D4 gene, recently related to preference for pork meat containing androstenone (described in [71]), was previously associated with adiposity, cognitive dietary restraint, and susceptibility to hunger in another study [108].

Despite these positive findings, very large GWAS on BMI or other health-related parameters have not found associations with SNPs in chemosensory genes [109-111], suggesting that their effects are likely to be very small and limited in predictive power.

\section{Combining Several Genetic Variants: The Polygenic Risk Score}

The evidence presented above suggests that a new paradigm may be needed to accelerate progress in understanding the relationships between food preferences and nutrition and health. Our findings [17] using the GWAS approach identified novel genes associated with food preferences with no known effects on chemosensory function. Thus, looking beyond the involvement of traditional chemosensory genes in food preferences may be important for gaining new insights.

Although GWA studies have led to progress in identifying common variations associated with many complex traits, the modest effect sizes have prevented risk prediction based on single genetic variants. More recently, polygenic risk score analyses that combine the effects of several genetic variants have shown some predictive ability for a wide range of complex traits [112]. In polygenic score (PGS) analysis, a set of SNPs identified in a GWAS is used to construct a polygenic score that is used for association testing or risk prediction.

To the best of our knowledge, polygenic risk score analyses for food preferences have not yet been conducted. Although the link between vegetable intake and adiposity measures was widely investigated [113-115], few studies focusing on the relationship between hedonic measures and 
adiposity have been conducted. These studies have found no or weak association [116-118], suggesting that this complex relationship could be modulated by several factors, including genetic ones. Therefore, here, we report the data obtained from a PGS analysis to evaluate the predictive power of SNPs associated with food liking on adiposity measures (BMI and fat mass). Data was collected from 1140 individuals belonging to two Italian cohorts (Friuli Venezia Giulia and Val Borbera). Further details on data collection, sample characteristics, and polygenic score analysis are reported in supplementary materials (File S1).

We constructed a PGS for vegetables (PGS-vegetables) based on 6 SNPs significantly associated with preferences for different vegetables in our previous work: rs28849980, rs10050951, rs8034691 for artichokes, rs2530184, rs9832668 for broccoli, and rs138369603 for chicory (see Table 2 in [17]).

For each individual, PGS-vegetables represents vegetable preference predicted by the combination of the above mentioned 6 SNPs. In the first step, the allele count for each SNP was weighted by its per-allele association with food preferences. Specifically, for each identified SNP, an individual's genotypic score ( 0,1 , or 2 for genotyped SNPs, or any value between $0-2$ for imputed SNPs) was multiplied by the effect size. SNPs were weighted such that a higher weight was associated with a higher preference for the associated vegetable. The final score (PGS-vegetables) was calculated for each individual by summing the values obtained in the first step across all six SNPs. Linear regression analysis was conducted to test the associations between adiposity measures (BMI and fat mass as dependent variables) and PGS-vegetables as the predictor variable, in models adjusted for sex, age, education level (as number of years of completed schooling), and physical activity (never/light/moderate/intense). Information on sample collection, genotyping, imputation, and phenotypes were reported in our previous works $[16,17]$. Table 2 shows that PGS-vegetables was a significant negative predictor of BMI and fat mass ( $p$-value $<0.05$ ), in addition to sex, age, education, and physical activity. Specifically, higher PGS-vegetables (corresponding to higher preferences for vegetable foods) was predictive of lower BMI and fat mass.

Table 2. Results of polygenic risk score analysis.

\begin{tabular}{ccc}
\hline Predictor Variables & BMI, Kg/m & Fat Mass, $\mathbf{~} g$ \\
\hline Sex, male & $\mathbf{2 . 8 5}(<0.0001)$ & $-0.67(0.2)$ \\
Age, years & $\mathbf{0 . 0 4}(<0.0001)$ & $\mathbf{0 . 0 9}(<0.0001)$ \\
Education level, years & $-0.14(<0.001)$ & $-0.26(0.002)$ \\
Physical activity & $-\mathbf{1 . 1 9}(<0.0001)$ & $-2.56(<0.0001)$ \\
Vegetables PGS & $-\mathbf{0 . 9 8}(\mathbf{0 . 0 2 8})$ & $-\mathbf{2 . 0 8}(\mathbf{0 . 0 2 3})$ \\
\hline
\end{tabular}

Beta and $p$-value in brackets are shown. In bold: significant results ( $p$-value $<0.05) . \mathrm{BMI}=$ Body Mass Index; PGS = Polygenic Score.

Although the PGS-vegetables variable accounted for only $0.28 \%$ of the variation in BMI and $0.33 \%$ of the variation in fat mass, the low number of SNPs included in the study could explain this finding.

These results on PGS represent a starting point in studying the polygenic effects of food preferences on health status. As the number of GWAS of food preferences increase, further studies considering more SNPs and other food categories should be conducted. Adopting the PGS approach would allow the development of more powerful genetic profiles to better predict the risk of disease.

\section{Conclusions}

In conclusion, the data reviewed here highlight the role of genetic variations in food preferences and their important contributions to nutrition and health.

There is a need to identify and investigate other genes involved in food preferences, besides those already implicated in olfactory and taste perception. These novel genes can be discovered through GWAS or other genomic approaches.

The use of polygenic risk analysis to assess associations between food preferences and disease outcomes could lead to important new insights in nutrition research. 
Supplementary Materials: The following are available online at http://www.mdpi.com/2072-6643/11/8/1735/s1, File S1: Data collection and polygenic score analysis.

Author Contributions: Conception and design of the review, A.R. and P.G., analysis and interpretation of data A.R., P.G., and M.P.C., writing the article and final approval of the version to be published, A.R., P.G., M.P.C., and E.C.

Funding: This research was funded by the Italian Ministry of Health (5x1000 to Institute for Maternal and Child Health IRCCS Burlo Garofolo). The funders had no role in the design of the study, data collection and analysis, decision to publish, or preparation of the manuscript.

Acknowledgments: A sincere thank you to Martina Bradaschia for her proofreading of this manuscript.

Conflicts of Interest: The authors declare that they have no competing interests.

\section{References}

1. Faust, J. A Twin Study of Personal Preferences. J. Biosoc. Sci. 1974, 6, 75-91. [CrossRef]

2. Birch, L.L. The relationship between children's food preferences and those of their parents. J. Nutr. Educ. 1980, 12, 14-18. [CrossRef]

3. Falciglia, G.A.; Norton, P.A. Evidence for a genetic influence on preference for some foods. J. Am. Diet. Assoc. 1994, 94, 154-158. [CrossRef]

4. Breen, F.; Plomin, R.; Wardle, J. Heritability of food preferences in young children. Physiol. Behav. 2006, 88, 443-447. [CrossRef]

5. Fildes, A.; Van Jaarsveld, C.H.; Llewellyn, C.H.; Fisher, A.; Cooke, L.; Wardle, J. Nature and nurture in children's food preferences. Am. J. Clin. Nutr. 2014, 99, 911-917. [CrossRef]

6. Smith, A.D.; Fildes, A.; Cooke, L.; Herle, M.; Shakeshaft, N.; Plomin, R.; Llewellyn, C. Genetic and environmental influences on food preferences in adolescence. Am. J. Clin. Nutr. 2016, 104, 446-453. [CrossRef]

7. Reed, D.R.; Bachmanov, A.A.; Beauchamp, G.K.; Tordoff, M.G.; Price, R.A. Heritable Variation in Food Preferences and Their Contribution to Obesity. Behav. Genet. 1997, 27, 373-387. [CrossRef]

8. Keskitalo, K.; Knaapila, A.; Kallela, M.; Palotie, A.; Wessman, M.; Sammalisto, S.; Peltonen, L.; Tuorila, H.; Perola, M. Sweet taste preferences are partly genetically determined: Identification of a trait locus on chromosome 16. Am. J. Clin. Nutr. 2007, 86, 55-63. [CrossRef]

9. Keskitalo, K.; Tuorila, H.; Spector, T.D.; Cherkas, L.F.; Knaapila, A.; Silventoinen, K.; Perola, M. Same genetic components underlie different measures of sweet taste preference. Am. J. Clin. Nutr. 2007, 86, 1663-1669. [CrossRef]

10. Törnwall, O.; Silventoinen, K.; Kaprio, J.; Tuorila, H. Why do some like it hot? Genetic and environmental contributions to the pleasantness of oral pungency. Physiol. Behav. 2012, 107, 381-389. [CrossRef]

11. Törnwall, O.; Silventoinen, K.; Keskitalo-Vuokko, K.; Perola, M.; Kaprio, J.; Tuorila, H. Genetic contribution to sour taste preference. Appetite 2012, 58, 687-694. [CrossRef]

12. Pallister, T.; Sharafi, M.; Lachance, G.; Pirastu, N.; Mohney, R.P.; MacGregor, A.; Feskens, E.J.M.; Duffy, V.; Spector, T.D.; Menni, C. Food Preference Patterns in a UK Twin Cohort. Twin Res. Hum. Genet. 2015, 18, 793-805. [CrossRef]

13. Reed, D.R.; Zhu, G.; Breslin, P.A.; Duke, F.F.; Henders, A.K.; Campbell, M.J.; Montgomery, G.W.; Medland, S.E.; Martin, N.G.; Wright, M.J. The perception of quinine taste intensity is associated with common genetic variants in a bitter receptor cluster on chromosome 12. Hum. Mol. Genet. 2010, 19, 4278-4285. [CrossRef]

14. Hwang, L.-D.; Lin, C.; Gharahkhani, P.; Cuellar-Partida, G.; Ong, J.-S.; An, J.; Gordon, S.D.; Zhu, G.; MacGregor, S.; Lawlor, D.A.; et al. New insight into human sweet taste: A genome-wide association study of the perception and intake of sweet substances. Am. J. Clin. Nutr. 2019, 109, 1724-1737. [CrossRef]

15. Pirastu, N.; Robino, A.; Lanzara, C.; Athanasakis, E.; Esposito, L.; Tepper, B.J.; Gasparini, P. Genetics of Food Preferences: A First View from Silk Road Populations. J. Food Sci. 2012, 77, S413-S418. [CrossRef]

16. Pirastu, N.; Kooyman, M.; Traglia, M.; Robino, A.; Willems, S.M.; Pistis, G.; Amin, N.; Sala, C.; Karssen, L.C.; Van Duijn, C.M.; et al. Genome-wide association analysis on five isolated populations identifies variants of the HLA-DOA gene associated with white wine liking. Eur. J. Hum. Genet. 2015, 23, 1717-1722. [CrossRef]

17. Pirastu, N.; Kooyman, M.; Traglia, M.; Robino, A.; Willems, S.M.; Pistis, G.; Amin, N.; Sala, C.; Karssen, L.C.; Van Duijn, C.; et al. A Genome-Wide Association Study in isolated populations reveals new genes associated to common food likings. Rev. Endocr. Metab. Disord. 2016, 17, 209-219. [CrossRef] 
18. Eriksson, N.; Wu, S.; Do, C.B.; Kiefer, A.K.; Tung, J.Y.; Mountain, J.L.; Hinds, D.A.; Francke, U. A genetic variant near olfactory receptor genes influences cilantro preference. Flavour 2012, 1, 22. [CrossRef]

19. Kim, U.-K.; Jorgenson, E.; Coon, H.; Leppert, M.; Risch, N.; Drayna, D. Positional Cloning of the Human Quantitative Trait Locus Underlying Taste Sensitivity to Phenylthiocarbamide. Science 2003, 299, 1221-1225. [CrossRef]

20. Guo, S.-W.; Reed, D.R. The genetics of phenylthiocarbamide perception. Ann. Hum. Biol. 2001, 28, 111-142.

21. Bufe, B.; Hofmann, T.; Krautwurst, D.; Raguse, J.D.; Meyerhof, W. The human TAS2R16 receptor mediates bitter taste in response to beta-glucopyranosides. Nat. Genet. 2002, 32, 397-401. [CrossRef]

22. Kuhn, C.; Bufe, B.; Winnig, M.; Hofmann, T.; Frank, O.; Behrens, M.; Lewtschenko, T.; Slack, J.P.; Ward, C.D.; Meyerhof, W. Bitter Taste Receptors for Saccharin and Acesulfame K. J. Neurosci. 2004, 24, 10260-10265. [CrossRef]

23. Pronin, A.N.; Xu, H.; Tang, H.; Zhang, L.; Li, Q.; Li, X. Specific Alleles of Bitter Receptor Genes Influence Human Sensitivity to the Bitterness of Aloin and Saccharin. Curr. Biol. 2007, 17, 1403-1408. [CrossRef]

24. Behrens, M.; Meyerhof, W. Bitter taste receptors and human bitter taste perception. Cell Mol. Life Sci. 2006, 63, 1501-1509. [CrossRef]

25. Mainland, J.D.; Matsunami, H. Taste Perception: How sweet it is (To be transcribed by you). Curr. Biol. 2009, 19, R655-R656. [CrossRef]

26. Fushan, A.A.; Simons, C.T.; Slack, J.P.; Manichaikul, A.; Drayna, D. Allelic Polymorphism within the TAS1R3 Promoter is Associated with Human Taste Sensitivity to Sucrose. Curr. Biol. 2009, 19, 1288-1293. [CrossRef]

27. Shigemura, N.; Shirosaki, S.; Sanematsu, K.; Yoshida, R.; Ninomiya, Y. Genetic and Molecular Basis of Individual Differences in Human Umami Taste Perception. PLoS ONE 2009, 4, e6717. [CrossRef]

28. Shigemura, N.; Shirosaki, S.; Ohkuri, T.; Sanematsu, K.; Islam, A.S.; Ogiwara, Y.; Kawai, M.; Yoshida, R.; Ninomiya, Y. Variation in umami perception and in candidate genes for the umami receptor in mice and humans. Am. J. Clin. Nutr. 2009, 90, 764S-769S. [CrossRef]

29. Dias, A.G.; Rousseau, D.; Duizer, L.; Cockburn, M.; Chiu, W.; Nielsen, D.; El-Sohemy, A. Genetic variation in putative salt taste receptors and salt taste perception in humans. Chem. Sens. 2013, 38, 137-145. [CrossRef]

30. Laugerette, F.; Passilly-Degrace, P.; Patris, B.; Niot, I.; Febbraio, M.; Montmayeur, J.-P.; Besnard, P. CD36 involvement in orosensory detection of dietary lipids, spontaneous fat preference, and digestive secretions. J. Clin. Investig. 2005, 115, 3177-3184. [CrossRef]

31. Keller, K.L.; Liang, L.C.H.; Sakimura, J.; May, D.; van Belle, C.; Breen, C.; Driggin, E.; Tepper, B.J.; Lanzano, P.C.; Deng, L.; et al. Common variants in the CD36 gene are associated with oral fat perception, fat preferences, and obesity in African Americans. Obesity 2012, 20, 1066-1073. [CrossRef]

32. Reed, D.R.; Xia, M.B. Recent Advances in Fatty Acid Perception and Genetics. Adv. Nutr. 2015, 6, 353S-360S. [CrossRef]

33. Ugawa, S. Identification of sour-taste receptor genes. Anat. Sci. Int. 2003, 78, 205-210. [CrossRef]

34. Ishimaru, Y.; Matsunami, H. Transient Receptor Potential (TRP) Channels and Taste Sensation. J. Dent. Res. 2009, 88, 212-218. [CrossRef]

35. Bachmanov, A.A.; Beauchamp, G.K. Taste receptor genes. Annu. Rev. Nutr. 2007, 27, 389-414. [CrossRef]

36. Bachmanov, A.A.; Bosak, N.P.; Lin, C.; Matsumoto, I.; Ohmoto, M.; Reed, D.R.; Nelson, T.M. Genetics of taste receptors. Curr. Pharm. Des. 2014, 20, 2669-2683. [CrossRef]

37. Hayes, J.E.; Wallace, M.R.; Knopik, V.S.; Herbstman, D.M.; Bartoshuk, L.M.; Duffy, V.B. Allelic variation in TAS2R bitter receptor genes associates with variation in sensations from and ingestive behaviors toward common bitter beverages in adults. Chem. Sens. 2011, 36, 311-319. [CrossRef]

38. Tepper, B.J. Nutritional Implications of Genetic Taste Variation: The Role of PROP Sensitivity and Other Taste Phenotypes. Annu. Rev. Nutr. 2008, 28, 367-388. [CrossRef]

39. Feeney, E. The impact of bitter perception and genotypic variation of TAS2R38 on food choice. Nutr. Bull. 2011, 36, 20-33. [CrossRef]

40. Hayes, J.E.; Feeney, E.L.; Allen, A.L. Do polymorphisms in chemosensory genes matter for human ingestive behavior? Food Qual. Prefer. 2013, 30, 202-216. [CrossRef]

41. Feeney, E.; O’Brien, S.; Scannell, A.; Markey, A.; Gibney, E.R. Genetic variation in taste perception: Does it have a role in healthy eating? Proc. Nutr. Soc. 2011, 70, 135-143. [CrossRef] 
42. Negri, R.; Di Feola, M.; Di Domenico, S.; Scala, M.G.; Artesi, G.; Valente, S.; Smarrazzo, A.; Turco, F.; Morini, G.; Greco, L. Taste perception and food choices. J. Pediatr. Gastroenterol. Nutr. 2012, 54, 624-629. [CrossRef]

43. García-Bailo, B.; Toguri, C.; Eny, K.M.; El-Sohemy, A. Genetic Variation in Taste and Its Influence on Food Selection. OMICS 2009, 13, 69-80. [CrossRef]

44. Chamoun, E.; Mutch, D.M.; Allen-Vercoe, E.; Buchholz, A.C.; Duncan, A.M.; Spriet, L.L.; Haines, J.; Ma, D.W.L. Guelph Family Health Study. A review of the associations between single nucleotide polymorphisms in taste receptors, eating behaviors, and health. Crit. Rev. Food Sci. Nutr. 2018, 58, 194-207. [CrossRef]

45. Eny, K.M.; Wolever, T.M.; Corey, P.N.; El-Sohemy, A. Genetic variation in TAS1R2 (Ile191Val) is associated with consumption of sugars in overweight and obese individuals in 2 distinct populations. Am. J. Clin. Nutr. 2010, 92, 1501-1510. [CrossRef]

46. Kulkarni, G.; Chng, T.; Eny, K.; Nielsen, D.; Wessman, C.; El-Sohemy, A. Association of GLUT2 and TAS1R2 Genotypes with Risk for Dental Caries. Caries Res. 2013, 47, 219-225. [CrossRef]

47. Ma, X.; Bacci, S.; Mlynarski, W.; Gottardo, L.; Soccio, T.; Menzaghi, C.; Iori, E.; Lager, R.A.; Shroff, A.R.; Gervino, E.V.; et al. A common haplotype at the CD36 locus is associated with high free fatty acid levels and increased cardiovascular risk in Caucasians. Hum. Mol. Genet. 2004, 13, 2197-2205. [CrossRef]

48. Dotson, C.D.; Vigues, S.; Steinle, N.I.; Munger, S.D. T1R and T2R receptors: The modulation of incretin hormones and potential targets for the treatment of type 2 diabetes mellitus. Curr. Opin. Investig. Drugs 2010, 11, 447-454.

49. Mackay, T.F. The genetic architecture of quantitative traits. Annu. Rev. Genet. 2001, 35, 303-339. [CrossRef]

50. Yang, J.; Manolio, T.A.; Pasquale, L.R.; Boerwinkle, E.; Caporaso, N.; Cunningham, J.M.; de Andrade, M.; Feenstra, B.; Feingold, E.; Hayes, M.G.; et al. Genome partitioning of genetic variation for complex traits using common SNPs. Nat. Genet. 2011, 43, 519-525. [CrossRef]

51. Rao, D. An Overview of the Genetic Dissection of Complex Traits. Adv. Genet. 2008, 60, 3-34.

52. Visscher, P.M.; Hill, W.G.; Wray, N.R. Heritability in the genomics era-Concepts and misconceptions. Nat. Rev. Genet. 2008, 9, 255-266. [CrossRef]

53. Zhu, M. Candidate Gene Identification Approach: Progress and Challenges. Int. J. Biol. Sci. 2007, 3, 420-427. [CrossRef]

54. Glanz, K.; Basil, M.; Maibach, E.; Goldberg, J.; Snyder, D. Why Americans eat what they do: Taste, nutrition, cost, convenience, and weight control concerns as influences on food consumption. J. Am. Diet. Assoc. 1998, 98, 1118-1126. [CrossRef]

55. Drewnowski, A.; Henderson, S.A.; Levine, A.; Hann, C. Taste and food preferences as predictors of dietary practices in young women. Public Health Nutr. 1999, 2, 513-519. [CrossRef]

56. Boesveldt, S.; De Graaf, K. The Differential Role of Smell and Taste For Eating Behavior. Perception 2017, 46, 307-319. [CrossRef]

57. Kim, U.K.; Drayna, D. Genetics of individual differences in bitter taste perception: Lessons from the PTC gene. Clin. Genet. 2005, 67, 275-280. [CrossRef]

58. Bufe, B.; Breslin, P.A.S.; Kühn, C.; Reed, D.R.; Tharp, C.D.; Slack, J.P.; Kim, U.-K.; Drayna, D.; Meyerhof, W. The Molecular Basis of Individual Differences in Phenylthiocarbamide and Propylthiouracil Bitterness Perception. Curr. Biol. 2005, 15, 322-327. [CrossRef]

59. Dinehart, M.; Hayes, J.; Bartoshuk, L.; Lanier, S.; Duffy, V. Bitter taste markers explain variability in vegetable sweetness, bitterness, and intake. Physiol. Behav. 2006, 87, 304-313. [CrossRef]

60. Keller, K.L.; Steinmann, L.; Nurse, R.J.; Tepper, B.J. Genetic taste sensitivity to 6-n-propylthiouracil influences food preference and reported intake in preschool children. Appetite 2002, 38, 3-12. [CrossRef]

61. Ullrich, N.V.; Touger-Decker, R.; O'sullivan-Maillet, J.; Tepper, B.J. PROP taster status and self-perceived food adventurousness influence food preferences. J. Am. Diet. Assoc. 2004, 104, 543-549. [CrossRef] [PubMed]

62. Hayes, J.E.; Duffy, V.B. Oral sensory phenotype identifies level of sugar and fat required for maximal liking. Physiol. Behav. 2008, 95, 77-87. [CrossRef] [PubMed]

63. Mennella, J.A.; Pepino, M.Y.; Reed, D.R. Genetic and environmental determinants of bitter perception and sweet preferences. Pediatrics 2005, 115, e216-e222. [CrossRef] [PubMed]

64. Ooi, S.-X.; Lee, P.-L.; Law, H.-Y.; Say, Y.-H. Bitter receptor gene (TAS2R38) P49A genotypes and their associations with aversion to vegetables and sweet/fat foods in Malaysian subjects. Asia Pac. J. Clin. Nutr. 2010, 19, 491-498. [PubMed] 
65. Shen, Y.; Kennedy, O.B.; Methven, L. Exploring the effects of genotypical and phenotypical variations in bitter taste sensitivity on perception, liking and intake of brassica vegetables in the UK. Food Qual. Prefer. 2016, 50, 71-81. [CrossRef]

66. Perna, S.; Riva, A.; Nicosanti, G.; Carrai, M.; Barale, R.; Vigo, B.; Allegrini, P.; Rondanelli, M. Association of the bitter taste receptor gene TAS2R38 (polymorphism RS713598) with sensory responsiveness, food preferences, biochemical parameters and body-composition markers. A cross-sectional study in Italy. Int. J. Food Sci. Nutr. 2018, 69, 245-252. [CrossRef] [PubMed]

67. Pirastu, N.; Kooyman, M.; Traglia, M.; Robino, A.; Willems, S.M.; Pistis, G.; D'Adamo, P.; Amin, N.; D’Eustacchio, A.; Navarini, L.; et al. Association Analysis of Bitter Receptor Genes in Five Isolated Populations Identifies a Significant Correlation between TAS2R43 Variants and Coffee Liking. PLoS ONE 2014, 9, e92065. [CrossRef] [PubMed]

68. Mennella, J.A.; Finkbeiner, S.; Reed, D.R. The proof is in the pudding: Children prefer lower fat but higher sugar than do mothers. Int. J. Obes. 2012, 36, 1285-1291. [CrossRef] [PubMed]

69. Wysocki, C.J.; Beauchamp, G.K. Ability to smell androstenone is genetically determined. Proc. Natl. Acad. Sci. USA 1984, 81, 4899-4902. [CrossRef] [PubMed]

70. Keller, A.; Zhuang, H.; Chi, Q.; Vosshall, L.B.; Matsunami, H. Genetic variation in a human odorant receptor alters odour perception. Nature 2007, 449, 468-472. [CrossRef] [PubMed]

71. Lunde, K.; Egelandsdal, B.; Skuterud, E.; Mainland, J.D.; Lea, T.; Hersleth, M.; Matsunami, H. Genetic Variation of an Odorant Receptor OR7D4 and Sensory Perception of Cooked Meat Containing Androstenone. PLOS ONE 2012, 7, e35259. [CrossRef] [PubMed]

72. Jaeger, S.R.; McRae, J.F.; Salzman, Y.; Williams, L.; Newcomb, R.D. A preliminary investigation into a genetic basis for cis-3-hexen-1-ol odour perception: A genome-wide association approach. Food Qual. Prefer. 2010, 21, 121-131. [CrossRef]

73. McRae, J.F.; Mainland, J.D.; Jaeger, S.R.; Adipietro, K.A.; Matsunami, H.; Newcomb, R.D. Genetic variation in the odorant receptor OR2J3 is associated with the ability to detect the "grassy" smelling odor, cis-3-hexen-1-ol. Chem. Senses 2012, 37, 585-593. [CrossRef] [PubMed]

74. Jaeger, S.R.; Pineau, B.; Bava, C.M.; Atkinson, K.R.; AMcRae, J.F.; Axten, L.G.; Chheang, S.L.; Beresford, M.K.; Peng, M.; Paisley, A.G.; et al. Investigation of the impact of sensitivity to cis-3-hexen-1-ol (green/grassy) on food acceptability and selection. Food Qual. Prefer. 2012, 24, 230-242. [CrossRef]

75. Etiévant, P.X.; Issanchou, S.N.; Bayonove, C.L. The flavour of muscat wine: The sensory contribution of some volatile compounds. J. Sci. Food Agric. 1983, 34, 497-504. [CrossRef]

76. Larsen, M.; Poll, L.; Callesen, O.; Lewis, M. Relations between the content of aroma compounds and the sensory evaluation of 10 raspberry varieties (Rubus idaeus L). Acta Agric. Scand. 1991, 41, 447-454. [CrossRef]

77. Tandon, K.; Baldwin, E.; Shewfelt, R. Aroma perception of individual volatile compounds in fresh tomatoes (Lycopersicon esculentum, Mill.) as affected by the medium of evaluation. Postharvest Biol. Technol. 2000, 20, 261-268. [CrossRef]

78. Mahattanatawee, K.; Rouseff, R.; Valim, M.F.; Naim, M. Identification and Aroma Impact of Norisoprenoids in Orange Juice. J. Agric. Food Chem. 2005, 53, 393-397. [CrossRef]

79. Jaeger, S.R.; McRae, J.F.; Bava, C.M.; Beresford, M.K.; Hunter, D.; Jia, Y.; Chheang, S.L.; Jin, D.; Peng, M.; Gamble, J.C.; et al. A Mendelian trait for olfactory sensitivity affects odor experience and food selection. Curr. Biol. 2013, 23, 1601-1605. [CrossRef]

80. Visscher, P.M.; Wray, N.R.; Zhang, Q.; Sklar, P.; McCarthy, M.I.; Brown, M.A.; Yang, J. 10 Years of GWAS Discovery: Biology, Function, and Translation. Am. J. Hum. Genet. 2017, 101, 5-22. [CrossRef]

81. Eriksson, N.; MacPherson, J.M.; Tung, J.Y.; Hon, L.S.; Naughton, B.; Saxonov, S.; Avey, L.; Wojcicki, A.; Pe'Er, I.; Mountain, J. Web-Based, Participant-Driven Studies Yield Novel Genetic Associations for Common Traits. PLoS Genet. 2010, 6, e1000993. [CrossRef] [PubMed]

82. Precone, V.; Beccari, T.; Stuppia, L.; Baglivo, M.; Paolacci, S.; Manara, E.; Miggiano, G.A.D.; Falsini, B.; Trifirò, A.; Zanlari, A.; et al. Taste, olfactory and texture related genes and food choices: Implications on health status. Eur. Rev. Med. Pharmacol. Sci. 2019, 23, 1305-1321. [PubMed]

83. Haznedaroglu, E.; Bakir-Coskun, N.; Bozkus, H.M.; Mentes, A. Association of Sweet Taste Receptor Gene Polymorphisms with Dental Caries Experience in School Children. Caries Res. 2015, 49, 275-281. [CrossRef] [PubMed] 
84. Robino, A.; Bevilacqua, L.; Pirastu, N.; Situlin, R.; Di Lenarda, R.; Gasparini, P.; Navarra, C.O. Polymorphisms in sweet taste genes (TAS1R2 and GLUT2), sweet liking, and dental caries prevalence in an adult Italian population. Genes Nutr. 2015, 10, 485. [CrossRef] [PubMed]

85. Dotson, C.D.; Shaw, H.L.; Mitchell, B.D.; Munger, S.D.; Steinle, N.I. Variation in the gene TAS2R38 is associated with the eating behavior disinhibition in Old OrderAmish women. Appetite 2010, 54, 93-99. [CrossRef] [PubMed]

86. Tepper, B.J.; Koelliker, Y.; Zhao, L.; Ullrich, N.V.; Lanzara, C.; D'Adamo, P.; Ferrara, A.; Ulivi, S.; Esposito, L.; Gasparini, P.; et al. Variation in the Bitter-taste Receptor GeneTAS2R38, and Adiposity in a Genetically Isolated Population in Southern Italy. Obesity 2008, 16, 2289-2295. [CrossRef]

87. Keller, M.; Liu, X.; Wohland, T.; Rohde, K.; Gast, M.-T.; Stumvoll, M.; Kovács, P.; Tonjes, A.; Böttcher, Y. TAS2R38 and Its Influence on Smoking Behavior and Glucose Homeostasis in the German Sorbs. PLoS ONE 2013, 8, e80512. [CrossRef]

88. Timpson, N.J.; Christensen, M.; Lawlor, D.A.; Gaunt, T.R.; Day, I.N.; Ebrahim, S.; Davey Smith, G. TAS2R38 (phenylthiocarba-mide) haplotypes, coronary heart disease traits, and eating behavior in the British Women's Heart and Health Study. Am. J. Clin. Nutr. 2005, 81, 1005-1011. [CrossRef]

89. Lipchock, S.V.; Mennella, J.A.; Spielman, A.I.; Reed, D.R. Human bitter perception correlates with bitter receptor messenger RNA expression in taste cells. Am. J. Clin. Nutr. 2013, 98, 1136-1143. [CrossRef]

90. Lipchock, S.V.; Spielman, A.I.; Mennella, J.A.; Mansfield, C.J.; Hwang, L.-D.; Douglas, J.E.; Reed, D.R. Caffeine Bitterness is Related to Daily Caffeine Intake and Bitter Receptor mRNA Abundance in Human Taste Tissue. Perception 2017, 46, 245-256. [CrossRef]

91. Archer, N.; Shaw, J.; Cochet-Broch, M.; Bunch, R.; Poelman, A.; Barendse, W.; Duesing, K. Obesity is associated with altered gene expression in human tastebuds. Int. J. Obes. 2019, 43, 1475-1484. [CrossRef] [PubMed]

92. Wu, S.V.; Rozengurt, N.; Yang, M.; Young, S.H.; Sinnett-Smith, J.; Rozengurt, E. Expression of bitter taste receptors of the T2R family in the gastrointestinal tract and enteroendocrine STC-1 cells. Proc. Natl. Acad. Sci. USA 2002, 99, 2392-2397. [CrossRef] [PubMed]

93. Kokrashvili, Z.; Mosinger, B.; Margolskee, R.F. Taste signaling elements expressed in gut enteroendocrine cells regulate nutrient-responsive secretion of gut hormones1234. Am. J. Clin. Nutr. 2009, 90, 822S-825S. [CrossRef]

94. Pham, H.; Hui, H.; Morvaridi, S.; Cai, J.; Zhang, S.; Tan, J.; Wu, V.; Levin, N.; Knudsen, B.; Goddard, W.A., 3rd; et al. A bitter pill for type 2 diabetes? The activation of bitter taste receptor TAS2R38 can stimulate GLP-1 release from enteroendocrine L-cells. Biochem. Biophys. Res. Commun. 2016, 475, 295-300. [CrossRef]

95. Kok, B.P.; Galmozzi, A.; Littlejohn, N.K.; Albert, V.; Godio, C.; Kim, W.; Kim, S.M.; Bland, J.S.; Grayson, N.; Fang, M.; et al. Intestinal bitter taste receptor activation alters hormone secretion and imparts metabolic benefits. Mol. Metab. 2018, 16, 76-87. [CrossRef]

96. Avau, B.; Rotondo, A.; Thijs, T.; Andrews, C.N.; Janssen, P.; Tack, J.; Depoortere, I. Targeting extra-oral bitter taste receptors modulates gastrointestinal motility with effects on satiation. Sci. Rep. 2015, 6, 15985. [CrossRef] [PubMed]

97. Jang, H.J.; Kokrashvili, Z.; Theodorakis, M.J.; Carlson, O.D.; Kim, B.J.; Zhou, J.; Kim, H.H.; Xu, X.; Chan, S.L.; Juhaszova, M.; et al. Gut-expressed gustducin and taste receptors regulate secretion of glucagon-like peptide-1. Proc. Natl. Acad. Sci. USA 2007, 104, 15069-15074. [CrossRef] [PubMed]

98. Behrens, M.; Meyerhof, W. Oral and Extraoral Bitter Taste Receptors. Results Probl. Cell Differ. 2010, 52, 87-99.

99. Finger, T.E.; Kinnamon, S.C. Taste isn't just for taste buds anymore. F1000 Biol. Rep. 2011, 3. [CrossRef]

100. Depoortere, I. Taste receptors of the gut: Emerging roles in health and disease. Gut 2014, 63, 179-190. [CrossRef]

101. Avau, B.; Depoortere, I. The bitter truth about bitter taste receptors: Beyond sensing bitter in the oral cavity. Acta Physiol. 2016, 216, 407-420. [CrossRef] [PubMed]

102. Feng, R.; Qian, C.; Liu, Q.; Jin, Y.; Liu, L.; Li, S.; Liao, Y.; Zhou, H.; Liu, W.; Rayner, C.K.; et al. Expression of sweet taste receptor and gut hormone secretion in modelled type 2 diabetes. Gen. Comp. Endocrinol. 2017, 252, 142-149. [CrossRef] [PubMed]

103. Lee, S.-J.; Depoortere, I.; Hatt, H. Therapeutic potential of ectopic olfactory and taste receptors. Nat. Rev. Drug Discov. 2018, 18, 116-138. [CrossRef] [PubMed]

104. Doty, R.L. Olfactory dysfunction in neurodegenerative diseases: Is there a common pathological substrate? Lancet Neurol. 2017, 16, 478-488. [CrossRef] 
105. Marin, C.; Vilas, D.; Langdon, C.; Alobid, I.; López-Chacón, M.; Haehner, A.; Hummel, T.; Mullol, J. Olfactory Dysfunction in Neurodegenerative Diseases. Curr. Allergy Asthma Rep. 2018, 18, 42. [CrossRef] [PubMed]

106. Riera, C.E.; Tsaousidou, E.; Halloran, J.; Follett, P.; Hahn, O.; Pereira, M.M.; Ruud, L.E.; Alber, J.; Tharp, K.; Anderson, C.M.; et al. The Sense of Smell Impacts Metabolic Health and Obesity. Cell Metab. 2017, 26, $198-211$. [CrossRef] [PubMed]

107. Mariman, E.C.M.; Szklarczyk, R.; Bouwman, F.G.; Aller, E.E.J.G.; Van Baak, M.A.; Wang, P. Olfactory receptor genes cooperate with protocadherin genes in human extreme obesity. Genes Nutr. 2015, 10, 465. [CrossRef] [PubMed]

108. Choquette, A.C.; Bouchard, L.; Drapeau, V.; Lemieux, S.; Tremblay, A.; Bouchard, C.; Vohl, M.-C.; Perusse, L. Association between olfactory receptor genes, eating behavior traits and adiposity: Results from the Quebec Family Study. Physiol. Behav. 2012, 105, 772-776. [CrossRef]

109. Locke, A.E.; Kahali, B.; Berndt, S.I.; Justice, A.E.; Pers, T.H.; Day, F.R.; Powell, C.; Vedantam, S.; Buchkovich, M.L.; Yang, J.; et al. Genetic studies of body mass index yield new insights for obesity biology. Nature 2015, 518, 197-206. [CrossRef]

110. Yengo, L.; Sidorenko, J.; Kemper, K.E.; Zheng, Z.; Wood, A.R.; Weedon, M.N.; Frayling, T.M.; Hirschhorn, J.; Yang, J.; Visscher, P.M. GIANT Consortium. Meta-analysis of genome-wide association studies for height and body mass index in 700000 individuals of European ancestry. Hum. Mol. Genet. 2018, 27, 3641-3649. [CrossRef]

111. Evangelou, E.; Warren, H.R.; Mosen-Ansorena, D.; Mifsud, B.; Pazoki, R.; Gao, H.; Ntritsos, G.; Dimou, N.; Cabrera, C.P.; Karaman, I.; et al. Genetic analysis of over 1 million people identifies 535 new loci associated with blood pressure traits. Nat. Genet. 2018, 50, 1755. [CrossRef] [PubMed]

112. Torkamani, A.; Wineinger, N.E.; Topol, E.J. The personal and clinical utility of polygenic risk scores. Nat. Rev. Genet. 2018, 19, 581-590. [CrossRef] [PubMed]

113. Ledoux, T.A.; Hingle, M.D.; Baranowski, T. Relationship of fruit and vegetable intake with adiposity: A systematic review. Obes. Rev. 2011, 12, e143-e150. [CrossRef]

114. Schwingshackl, L.; Hoffmann, G.; Kalle-Uhlmann, T.; Arregui, M.; Buijsse, B.; Boeing, H. Fruit and Vegetable Consumption and Changes in Anthropometric Variables in Adult Populations: A Systematic Review and Meta-Analysis of Prospective Cohort Studies. PLoS ONE 2015, 10, e0140846. [CrossRef] [PubMed]

115. Nour, M.; Lutze, S.A.; Grech, A.; Allman-Farinelli, M. The Relationship between Vegetable Intake and Weight Outcomes: A Systematic Review of Cohort Studies. Nutrients 2018, 10, 1626. [CrossRef] [PubMed]

116. Duffy, V.B.; Hayes, J.E.; Sullivan, B.S.; Faghri, P. Surveying food and beverage liking. Ann. N. Y. Acad. Sci. 2009, 1170, 558-568. [CrossRef] [PubMed]

117. Laureati, M.; Bertolia, S.; Bergamaschi, V.; Leone, A.; Lewandowski, L.; Giussani, B.; Battezzati, A.; Pagliarini, E. Food neophobia and liking for fruits and vegetables are not related to Italian children's overweight. Food Qual. Prefer. 2015, 40, 125-131. [CrossRef]

118. Concas, M.P.; Catamo, E.; Biino, G.; Toniolo, D.; Gasparini, P.; Robino, A. Factors associated with food liking and their relationship with metabolic traits in Italian cohorts. Food Qual. Prefer. 2019, 75, 64-70. [CrossRef]

(C) 2019 by the authors. Licensee MDPI, Basel, Switzerland. This article is an open access article distributed under the terms and conditions of the Creative Commons Attribution (CC BY) license (http://creativecommons.org/licenses/by/4.0/). 